\title{
15 Sexual and gender-based violence in Uganda during the COVID-19 pandemic
}

\author{
New and old lessons for the \\ criminal justice system
}

\section{Lillian Tibatemwa-Ekirikubinza, $\mathrm{PhD}$}

\section{Introduction}

In March 2020, the World Health Organization (WHO) declared the COVID19 outbreak a pandemic of international concern. The Ugandan government responded by adopting a multi-sectoral approach with 34 policy measures, including the closure of educational institutions, restrictions on vehicle movements, a dawn-to-dusk curfew, and a halt to non-essential economic activities. The government's response to the crisis meant that the majority of Ugandans were confined to their homes.

Global research indicates that national emergencies lead to increased levels of sexual and gender-based violence (SGBV) (32nd RCRC Conference, 2015), and there is growing evidence that the COVID-19 pandemic has led to an increase in the incidence of sexual violence around the world (Peterman et al., 2020). The first part of this chapter deals with the impact of pandemic-related restrictions on the incidence of rape and defilement in Uganda. ${ }^{1}$ The chapter also evaluates the response of the criminal justice system - the Uganda Police, the Office of Public Prosecution (OPP), and the judiciary-to the current crisis. In Uganda, each police station has a gender desk that receives and manages sexual assault cases. A case file is compiled for each sexual assault reported, which is then investigated and finally forwarded to the prosecutor office for review. The OPP is mandated to institute criminal proceedings against suspected offenders. While this chapter is primarily based on an analysis of records from the Uganda Police, the OPP, and the judiciary, information was also gathered through interviews with officials from these three institutions.

The second part of the chapter places sexual violence against women within the socio-cultural context of Ugandan society. This is important, because emergencies may escalate women's vulnerability to sexual abuse, but they are often not the cause of the abuse. Like any other social phenomenon, rape can only be fully understood by considering the broad social context within which it occurs. To understand sexual encounters between men and women in Uganda, the discussion must be placed within the discourse of gender in a patriarchal society. While the 
country's judiciary is being called upon to play a central role in protecting women's right to protection against sexual violence during the current crisis, violence is not rooted in the pandemic. This chapter interrogates the theory that a judge's decision is grounded in the society in which it takes place, and that gender stereotypes and myths are embedded in judicial processes. To demonstrate a correlation between gender notions and the outcome of a rape trial, the results of a study I conducted on community perceptions of rape are juxtaposed with an analysis of judicial processes applied in rape trials. It is assumed that a judge's preconceived notions on gender, sex, and sexuality in a patriarchal society may affect the outcome of a trial and hamper women's access to justice. Any recommendation for improving women's access to justice during emergencies must, therefore, unearth the failures of the justice system to protect the rights of victims of sexual abuse in non-emergency situations.

\section{Pandemic-related restrictions and sexual violence against women}

A survey by the Uganda Association of Women Lawyers reveals that the pandemic led to a spike in cases of domestic and sexual violence during the lockdown (Musiime, 2020). For example, teenage pregnancies are reported to have increased during the school closures. The closure of schools can result in girls spending more time with the opposite sex, increasing the likelihood that they will engage in risky sexual behavior and be exposed to sexual violence and exploitation (World Vision, 2020). School closures also heighten the vulnerability of children to sexual abuse by people living in close proximity to their homes. According to the United Nations Population Fund (UNFPA), teenage pregnancies in Uganda increased by an estimated 1.62\% in 2020 compared with the last three years (UNFPA, 2020).

Despite the increase in domestic and sexual violence, the incidence of rape and defilement reported to the police in Uganda fell in the first half of 2020. A report by Uganda's Criminal Investigation Directorate shows that reported cases of defilement fell by $5.2 \%$ between January and June 2020. In this period, a total of 6,838 cases of defilement were reported to the police, lower than 7,216 cases reported between January and June 2019 (Figure 15.1). The records also show that 749 rape cases were reported to the police in the first half of 2020, lower than 770 cases reported in the same period in 2019, representing a decrease of $2.7 \%$. It is, therefore, clear that the escalation of sexual assault reported at the community level during the pandemic has not been fully reflected in the number of cases reported to the police. The decrease in the level of reporting was likely due to victims being unable to access the police and other services as a result of restrictions on movement, as the number of cases increased sharply once the restrictions were eased.

\section{Police trends: Kabalagala and Katwe police stations}

Data collected in collaboration with the Criminal Investigation Department reveal that Katwe and Kabalagala police stations ${ }^{2}$ recorded a drop in reported 


\section{CASES OF DEFILEMENT \& RAPE REPORTED TO POLICE PRE \& DURING COVID -19}

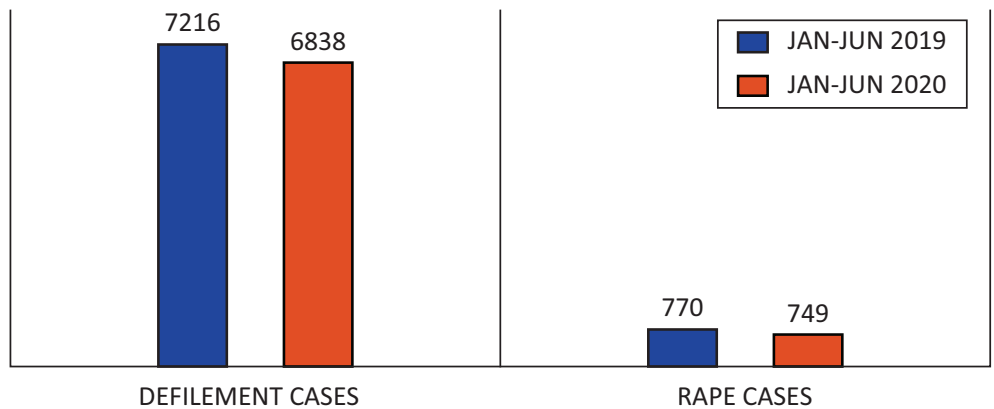

Figure 15.1 Incidence of rape and defilement reported to the police Source: Uganda Criminal Investigation Directorate, September, 2020.

rape and defilement cases, although they did show a possible link between stayat-home orders and the sexual offenses committed. A review of 50 case files (33 related to defilement, 19 to aggravated defilement, and 17 to rape) at both police stations shows that most incidents of rape and defilement during the lockdown were committed by people who knew or resided or worked close to the victim, such as family members, friends of the family, neighbors, or service providers (e.g., barbers, boda riders, ${ }^{3}$ food vendors, etc.) (Figure 15.2). ${ }^{4}$ The abuse frequently took place at private residences, although pathways, football pitches, and plantations were also recorded as crime sites. Most of the incidents occurred during the daytime, and children were often defiled in either their parents' or neighbors' homes. Assaults committed by people close to the victim, coupled with the continued proximity of the perpetrator to the victim, may have made it difficult for some victims to report the assault to the police.

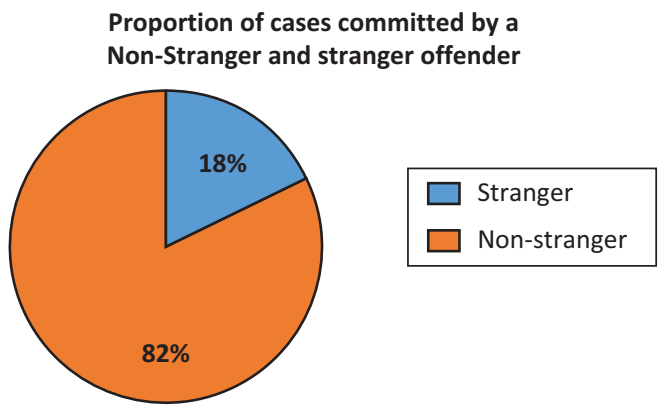

Figure 15.2 Proportion of cases committed by a non-stranger or stranger Source: Kabalagala and Katwe police records, accessed September, 2020. 
- Number of cases reported

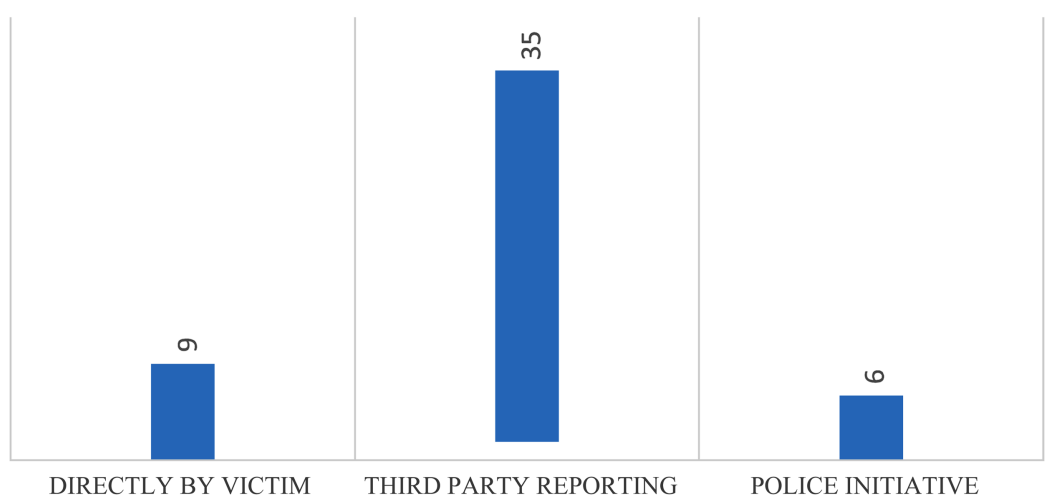

Figure 15.3 Cases of rape and defilement by source of reporting Source: Kabalagala and Katwe police records, accessed September, 2020.

Data also show that restrictions on economic activities, which led to the need for alternative sources of income, increased women's vulnerability to sexual abuse. For example, some women were assaulted by men who had promised to help them acquire employment in essential sectors. Furthermore, confinement at home led to an increase in the use of the internet and social media such as WhatsApp and Facebook. With this came an increase in the sharing of nude images, which was interpreted by some perpetrators as implied consent to sex.

Most rape and defilement cases processed at the Katwe and Kabalagala police stations were reported by third parties. Out of the 50 cases reviewed, 9 were reported by the victims, 35 were reported by third parties, and 6 were the result of community policing (Figure 15.3). This may be an indication that the police need better tools and training to identify signs of abuse as they engage with members of the community.

\section{Use and limitations of technology}

The police in Uganda have set up a 24/7 toll-free support line under the Department of Child and Family Protection Unit to receive reports of SGBV. It has been popularized on various social media platforms, along with the 116 Sati toll-free support line established in 2014 by the Ministry of Gender, Labor and Social Development (MGLSD) to encourage the reporting of child rights violations.

In September, 2020, the MGLSD scaled up the digital platform SafePal, which was created in 2015 with support from the UNFPA, to respond to the challenge of low levels of reporting of sexual violence (Songa, 2020). SafePal enables survivors to report cases confidentially and access information on psychosocial, legal, and medical services. Participating organizations include ActionAid, Naguru 
Teenage Center and Center for Domestic Violence Prevention, and the Uganda Police Child and Family Protection Unit. When a case is submitted, SafePal instantly notifies the relevant service provider so that they reach out to the victim. Incident reports submitted are usually attended to within 72 hours. The identity of the person who reported the incident is recorded with a unique code for use when there is a need to contact them to gather evidence.

While the use of technology can make it easier and more efficient to report and manage sexual abuse cases, innovative applications must be grounded in the lived realities of the targeted group. For example, many solutions that utilize information and communication technologies (ICT) assume that victims have access to phones. However, Groupe Speciale Mobile Association reports that women have a harder time accessing digital technologies and the internet than men because of high financial costs and high levels of technology illiteracy. A 2015 Uganda Communications Commission survey on access and use of ICT revealed that $44 \%$ of women owned and could use a phone, much lower than $62 \%$ of men (Women of Uganda Network, 2020). The survey also showed that only $15 \%$ of women interviewed had used a computer or the internet in the last three months preceding the survey, lower than $21 \%$ of men. Therefore, the digitalization of judicial practices can especially limit women's access to justice.

The use of phone services to report instances of abuse also has logistical and privacy challenges. The chief executive officer of the Uganda Association of Women Lawyers, Ms. Lilliane Adriko, has observed that it may be difficult for officers to follow up with victims who have reported their abuse by using a phone from a third party. For example, there could be a breach of privacy if the owner of the phone wants to know why the victim or the police need the phone. In addition, toll-free support lines are unevenly distributed across the country, and counseling services are harder to provide to victims over the phone. Finally, there may be inadequate capital and human resources to meet the demand created by digital platforms. For example, a survivor who calls a service center may expect to be physically rescued, but the police may not have the resources to transport and support the victim. Nevertheless, mobile applications to report sexual abuse have been increasingly used during the lockdown, especially by urban youth, university students, and women in the corporate sector. The perception that these applications can protect the identity of users has made them popular throughout the country (Songa, 2020).

\section{Community policing}

As a member of the National Joint Security Task Force and charged with enforcing COVID-19 prevention measures, the police have unrestricted access to communities. Using this privilege, the Department of Sexual and Child Offences has scaled up community policing and prioritized the reporting of sexual abuse. However, the success of the department's interventions has been limited by challenges such as a shortage of fuel to facilitate the continuous and timely response of the police. The unfavorable public opinion of the police has also made it more 
complicated for community liaison officers to investigate reports of sexual abuse (Kamya, 2020).

\section{Social media as a source of information}

During the lockdown, the police in Uganda have followed leads on social media and investigated cases that trended online, with some cases forwarded to the OPP. These efforts were, however, hampered by the limited ability of the police to collect and verify information from social media platforms. Furthermore, the training offered to the Uganda Police Force on identifying sexual assault on the internet has been very limited.

\section{Media campaigns}

In August and September 2020, the MGLSD spearheaded media campaigns to raise awareness and respond to the increase in SGBV during the COVID-19 pandemic. The campaign adopted a multi-sectoral approach, and experts from the different government agencies, including the police, shared data on reporting and information on adopted strategies.

\section{Office of Public Prosecution}

There was an increase in the number of cases of SGBV that were sanctioned by the OPP for the prosecution during the COVID-19 lockdown (Figure 15.4). ${ }^{5}$

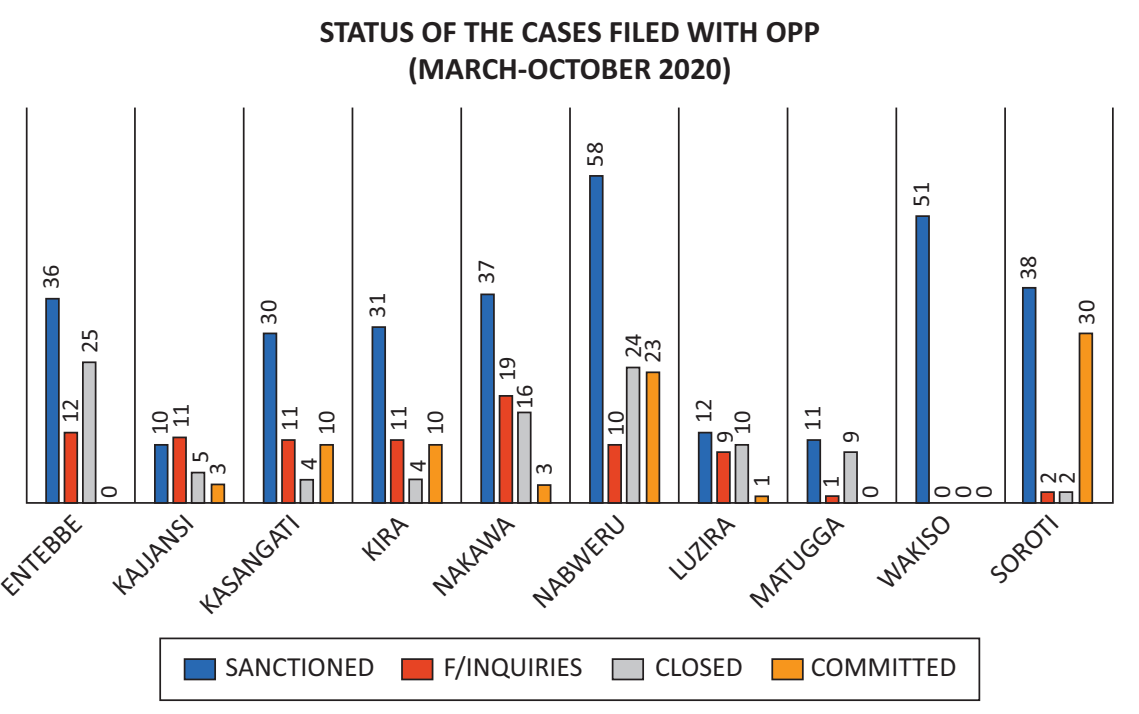

Figure 15.4 Cases filed with the OPP between March and October, 2020 by status Source: OPP, November, 2020. 
Data from ten police stations across Uganda, which show that more women than men were sexually assaulted, also point to a correlation between the number of SGBV cases sanctioned and urbanization. The OPP sanctioned more cases in large cities such as Entebbe, Nakawa, and Nabweru than in smaller cities such as Kajjansi, Luzira, and Matugga. This is expected, since judicial systems are more concentrated in urban areas, and residents of major metropolitan areas tend to be more knowledgeable about the justice system than people living in small towns or rural areas. Urban residents are also less likely than their rural counterparts to subscribe to a culture of silence when dealing with sexual assault.

During the lockdown, there were 314 cases sanctioned by the OPP in 10 jurisdictions, of which 118 cases $(37.5 \%)$ were withdrawn. This means that for every three cases sanctioned by the OPP, one case was closed. The unwillingness of the witness to testify was the main reason for the withdrawal of sexual assault cases.

\section{Pandemic-related measures and restrictions on the prosecution}

The OPP is not recognized as an essential service in the country's COVID-19 National Response Plan. According to Ms. Wakooli, head of the Sexual Offences Department, this compromised not only the work of prosecutors but also that of the criminal justice system as a whole. She stated: "It is important to note that the prosecutors 'own' criminal cases, a case cannot be tried in court unless it has been filed by the OPP." Restrictions on movement made it difficult for prosecutors to access their chambers and the courts and interview witnesses. As a result, even cases that made it to court suffered significant delays.

To cope with the challenges imposed by pandemic-related restrictions, the OPP increased its use of technology to facilitate a safe work environment. Some prosecutions were conducted online using digital tools such as Zoom, although these efforts had a minimal impact on proceedings outside of Kampala due to limited training of prosecutors in the use of technology. The government should consider prosecutors essential workers during emergencies, and they must be properly trained in the use of digital tools (e.g., a training module on virtual prosecution could be developed). The OPP should also procure relevant ICT equipment to ensure that its offices around the country can utilize remote technologies.

\section{The courts}

The Chief Justice issued guidelines for courts during the lockdown to prevent the spread of COVID-19. For criminal cases, all in-person court appearances were suspended; proceedings were to be conducted using video conferencing whenever possible, and courts were instructed to continue to handle certificates of urgency and taking pleas for serious cases and bail applications, although only the parties and their lawyers could be present in court.

Although in-person court appearances were suspended, the police continued to arrest criminal suspects. This meant that courts had to use audio and video conferencing to take the pleas of those arrested. The Judicature Audio-Visual 
Rules No. 26 of 2016 enumerate the circumstances under which witnesses can give evidence through electronic means. These include proceedings relating to sexual offenses. An audio-visual link facility was established at the Buganda Road Chief Magistrate's Court. While launching the facility in 2016, the Chief Justice emphasized its value in promoting the rights of child witnesses who are victims of sexual violence. At the launch, a 16-year-old victim of defilement became the first person in Uganda to give evidence in court through an audiovideo link.

However, following the issuance of the COVID-19 guidelines, not a single case of sexual assault has been handled using the audio-video link facility at the Buganda Chief Magistrate's Court. While the facility has been used by all the courts in Kampala and its surrounding areas, the heavy traffic has made it near impossible to conduct full trials. Instead, the facility has been used for plea taking, hearings for bail applications and plea bargains, and the delivery of judgments. As is the norm in criminal justice, the judicial system has focused on the rights of accused persons and failed to acknowledge the need to expedite the adjudication of sexual assault cases.

\section{Magistrate Courts in Nabweru and Makindye}

Between March 21 and June 2020, over 200 criminal cases were registered in the Chief Magistrate Court in Nabweru, of which only 33 cases involved sexual assault (Table 15.1). In 32 of the sexual assault cases, the victim and the perpetrator knew each other, and 32 offenses occurred at the perpetrator's residence. In 28 of these cases, the victims were school-going adolescents. These findings validate the argument that school closures increase the vulnerability of school-going children to sexual abuse by people living in close proximity to them. Sixteen of the victims were reportedly pregnant as a result of the defilement, which is supported by UNFPA data that project an increase in teenage pregnancies in Uganda in 2020. Also, a 2020 study by World Vision International shows that school closures during crises can result in girls spending more time with the opposite sex, increasing the likelihood of engaging in risky sexual behavior and raising the risk of sexual violence and exploitation (World Vision, 2020).

Table 15.1 Nabweru Chief Magistrate's Court

\begin{tabular}{lc}
\hline Offense & Number of cases \\
\hline Aggravated defilement & 2 \\
Simple defilement & 27 \\
Attempted defilement & 2 \\
Rape & 0 \\
Attempted rape & 2 \\
Child-to-child sex & 0 \\
\hline
\end{tabular}

Source: Nabweru Chief Magistrate Court records, accessed September 2020. 
Table 15.2 Makindye Chief Magistrate Court

\begin{tabular}{lllll}
\hline Category of offense & Number of cases & $\%$ & Total cases & $\%$ \\
\hline Aggravated defilement & 15 & 33.3 & 39 & 87 \\
Defilement & 24 & 53.3 & & \\
Rape & 4 & 9 & 6 & 13 \\
Attempted rape & 2 & 4.4 & & \\
Grand Total & 45 & 100 & 45 & 100 \\
\hline
\end{tabular}

Source: Makindye Chief Magistrate Court records, accessed September, 2020.

During the lockdown, 45 sexual offenses were reported to the Chief Magistrate Court in Makindye, 39 of which (87\%) involved defilement and $6(13 \%)$ involved rape (Table 15.2). The majority of the accused (64.4\%) were subjected to pre-trial detention, compared with more than one-third (35.6\%) who were granted bail pending trial. Under normal circumstances, it is rare in Uganda to grant bail to people accused of serious offenses before they have spent 180 days in pre-trial detention. According to interviews with the magistrates in Nabweru and Makindye, the trend of judicial officers being more willing to grant bail was the result of efforts to curtail the spread of COVID-19 by reducing the prison population. This trend is similar to that reported by Save the Children International in the northern district of Adjumani-the police released men suspected of defilement back into the community after 48 hours because the OPP was closed due to the pandemic (Save the Children, 2020).

Both magistrates reported an increase in bail jumping during the lockdown, and there were more instances of witnesses not showing up to court when suspects did turn up. The economic hardship caused by the pandemic has made it harder for victims to afford transportation to court. This has been exacerbated by the rising cost of public transportation linked to the adoption of social distancing measures, which has resulted in vehicles carrying fewer passengers on each route. The OPP needs to ensure that victims and witnesses have the means necessary to be in court when they are needed. One case that clearly shows the negative impact of COVID-19 restrictions on the administration of justice in Makindye was the release of a 48-year-old man who defiled a 14-year-old girl. The court was informed by the prosecution that there was no available transport to the prison for the accused, which meant that prosecutors could not object to the bail application.

Aside from efforts to reduce the prison population, there are also other factors that have led officials to be more willing to grant bail, accept plea bargains, and make use of non-custodial sentences. For example, in some defilement cases involving girls aged between 16 and 18 and men in their early twenties, there was evidence that the sexual act was consensual, even though a technical offense had been committed. However, no person accused of rape was granted bail pending trial during the lockdown period. Efforts to reduce the prison population have also resulted in an increase in the use of plea bargaining, which has led to shorter 
prison sentences (e.g., the average sentence of sexual assault offenders at both courts is six months) and more frequent use of non-custodial sentences such as cautions and community service orders.

Delay in adjudication is one potential reason for the high attrition rate in sexual assault cases in Uganda. Policymakers need to study best practices from other countries that have implemented effective strategies to enable women to access judicial services during the current crisis. For example, Ethiopia has continued to hear domestic violence cases with minimal interruption (Huaxia, 2020). Other countries are using virtual means to enable domestic violence survivors to utilize teleconferencing during court proceedings. A report by the United Nations High Commissioner for Refugees (UNHCR) points out that Burundi and Ethiopia have recognized SGBV services as essential in their COVID-19 national response plans. Both countries have facilitated access to judicial services and personal protective equipment and lifted movement restrictions for SGBV case workers (UNHCR, 2020).

\section{Sexual violence, the socio-cultural context, and the judicial system}

The police and the OPP have discretion in determining which cases are worth pursuing. When determining which cases to pursue, officers are aware of the principles that guide the courts in their decision to acquit or convict an accused. Officers file cases in court where, in their view, there is a reasonable chance of conviction. Therefore, any attempts to improve the quality of justice for victims of sexual abuse must include an evaluation of the workings of the judicial system. Moreover, judges are influenced by social norms, and their preconceived notions on gender, sex, and sexuality in a patriarchal society may negate women's access to justice in a rape trial.

To show the correlation between gender notions and the outcome of a rape trial, the results of a rape study that I conducted, which included interviews with 120 Ugandans on community perceptions of rape, were juxtaposed with the results of an analysis of judicial processes applied in rape trials. The interviews focused on the respondents' understanding of consent in sexual encounters, and the analysis of judicial processes focused on the Zuma rape trial (The State $v$. Jacob Gedleyihlekisa Zuma) because of the global interest it elicited. Mr. Jacob Zuma, the former President of South Africa, was charged in the High Court on December 6, 2005. He was accused of raping a 31-year-old woman. He admitted to having had sexual intercourse with the complainant but stated that it was consensual. While the trial was in South Africa, the effect of patriarchy on notions of sexuality in South Africa is assumed to be similar to that in Uganda.

\section{Gender, patriarchy, and gender justice}

The rape study adopted a generally accepted definition of gender as the socially constructed roles, behaviors, and attributes that a given society typically associates with 
and considers appropriate for males and females, respectively. Ugandan society has cultural norms that determine gender expression and roles. Gender is hierarchical and produces inequalities that intersect with other social and economic inequalities. A patriarchal society is defined as that which consists of a male-dominated power structure throughout organized society and in individual relationships. Under patriarchy, men have power over women simply because they are male. Ugandan society is defined as patriarchal, and its structure is based on a hierarchical system of oppression, where men as a class have power over women. To mitigate the effects of patriarchal society, Uganda's constitution enshrines the equal rights of women and men and prohibits laws and cultural, customary, and traditional practices that undermine the status of women (Constitution of Uganda, 1995).

Socially constructed roles shape women's access to justice. An understanding of gender and patriarchy by actors in the justice system is critical to any discussion of gender justice. Also, to understand sexual encounters between men and women, it is crucial that the discussion is placed within the discourse of gender in a patriarchal society. In its narrowest sense, access to justice refers to the formal ability to appear in a court of law. More broadly, however, access to justice interrogates the wider social context of a legal system. It probes the systemic barriers faced by different groups in the community in their attempt to use the services made available by the established institutions. Access to justice looks beyond equality of opportunity and aims to achieve equality of outcomes by addressing the barriers faced by those trying to access the judicial system (McHale, 2016). True access to justice must be considered in light of social variables that have historically had a negative impact on the ability of certain groups to access justice. It follows that gender justice involves efforts to end the inequalities between women and men that are produced and reproduced in the family, the community, and state institutions such as courts. In the context of a rape trial, it is important to evaluate the experiences of female victims as their complaints are processed through the justice system.

\section{Statutory law on rape}

Uganda's Penal Code Act (1950) defines rape as having sexual intercourse with a woman without her consent (Section 123). Prosecutors must prove that as a matter of fact there was no consent. They must also deal with the state of mind of the accused and prove that he knew that the woman was not consenting or was reckless as to whether or not she was consenting. If the accused establishes that he held an honest belief that the complainant was consenting, even if that belief was not reasonable, he would be free of criminality (DPP v. Morgan, 1976). The position of the law, as stated by the House of Lords in the United Kingdom, has been adopted by Ugandan and South African courts as well as many other commonwealth jurisdictions.

\section{Myths, beliefs, and stereotypes on sex and sexuality}

A man may wrongly believe a woman is consenting to sexual relations because of stereotypical beliefs and rape myths held in society. Lonsway and Fitzgerald 
(1994) define rape myths as "attitudes and beliefs that are generally false but are widely and persistently held, and that serve to deny and justify male sexual aggression against women" (p.134). The rape study that I conducted, which consisted of interviews with 120 men and women in Uganda, reveals that a slight majority $(52 \%)$ agree that a man is entitled to sex with a woman on whom he has spent money. With $55 \%$ of men and $48 \%$ of women agreeing with the statement, the difference between men and women is insignificant. The majority (60\%) of respondents under the age of 35 did not agree with the statement, while more than two-thirds (70\%) of respondents over the age of 35 agreed.

In terms of perceptions, one male respondent asked, "Why would a man who is neither your father nor brother give you money?" Other respondents said that men feel used by women who repeatedly accept financial favors and then refuse to have sex with them. Many women also held the view that to accept numerous favors from a man and then deny him sex was dishonest: "if you have no intentions of sleeping with him, reject his favors." It is clear that many in Uganda perceive financial favors as an investment and that the woman's consent is thereafter assumed. Because Uganda is a patriarchal society, men have greater access to the country's socio-economic resources. Within the context of rape, men's economic privilege is often translated into entitlement to women's bodies. It is, therefore, no surprise that a man who promised to help an unemployed woman access work during the pandemic would expect sex in return.

To the question of whether a man has the right to insist on sex after he and a woman have returned to his apartment after a date, the majority (53\%) of the respondents answered yes, with $63 \%$ of men and $42 \%$ of women saying yes-a significant difference between men and women. Fewer younger people answered in the affirmative, as only $30 \%$ and $40 \%$ of young women and men, respectively, said yes.

Date rape is closely linked with the issue of men raping women on whom they have spent or "invested" money. In Uganda, it is generally expected that the man pays for dinner or other activities when the parties have an intimate relationship or where there are indications of a romantic relationship. Also, the man is usually the person who will suggest that the two go out. Therefore, some of the observations made regarding the economic context of rape are also relevant in the context of date rape.

The majority of respondents also interpreted a woman's voluntary presence at a man's home as "asking" for it, meaning that the woman had agreed to sex by visiting the man's home. According to many of the interviewees, "A mature woman knows that if butter is placed near fire, it melts-if you go to a man's house but resist his sexual advances and he forces you into sex, you cannot blame him." One female respondent said that "she would have taken herself to the man's house and by so doing she stimulated him to have sex with her." Others asked, "How can you give a dog meat and then instruct it not to eat it?" Ironically, this opinion is in stark contrast to a picture of a disciplined dog next to a bucket of meat, which appeared in a local daily newspaper in 2015 (Figure 15.5). 


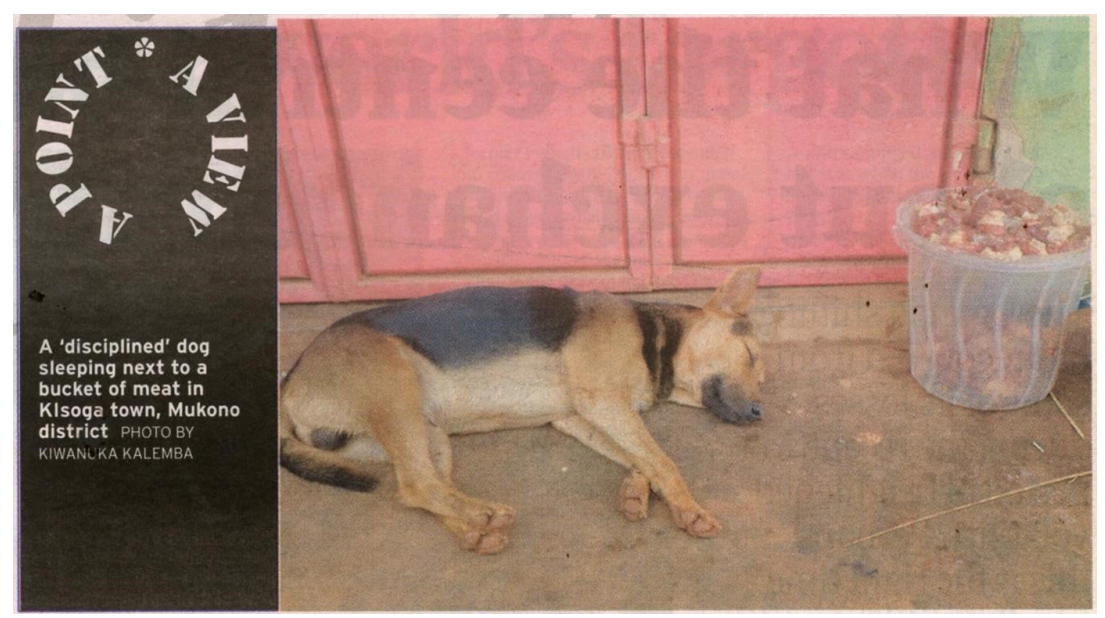

Figure 15.5 Picture of a disciplined dog Source: Kalemba, K. (2015, December 19). A "disciplined" dog sleeping next to a bucket of meat in Kisoga town, Mukno district. Saturday Vision.

The prevailing argument expressed by many of the respondents is that a woman should not go to a man's home after a date if she does not want to have sex with him, and a woman should know that sex is expected if she goes to a man's house. This perception was crudely supported by one male respondent, who stated that a woman cannot undress in the presence of a man and then claim she is scared of an erect penis. In the eyes of the majority, a woman's voluntary presence in a man's private space and/or relationship to the man in question can function as a stand-in for consent, or it renders her consent unnecessary. Others saw the woman's presence in the man's home as implied consent and stated, "Women will not verbally communicate consent to sex and if you make sexual advances and she rejects you, consider it feigned resistance; women say no when they mean yes; if in such circumstances you do not 'force' her into action, she would believe that you are impotent." The results of this study are in line with observations made by Moore et al. (2007) in a study of sexual relationships in sub-Saharan Africa. She found that the relationship between individuals and the circumstances under which sexual intercourse occurs influence an individual's perception of what constitutes sexual coercion. Similarly, Giarruso et al. (1979) report that some Americans do not regard non-consensual sex within a dating relationship as rape, even if a man coerces the woman. Moreover, a study carried out by Stets and Pirog-Good (1989) in the United States shows that some Americans believe it is justified for a man to have sex with a woman against her will if the woman allows the man to pay for all expenses during a date.

In response to the question of whether kissing and fondling in a secluded place indicate that a woman is willing to have sexual intercourse, $85 \%$ of the respondents said yes, and a majority did not consider it rape if under these 
circumstances the man uses force to have sex with the woman. Interestingly, more women (97\%) than men (73\%) answered yes, with one female respondent stating, "Girls are very cautious; if she is not ready for sex, she cannot engage in such deep intimacy and in a secluded place." While a slim majority $(53 \%)$ of respondents younger than 35 years old answered no, all the young women perceived kissing and fondling in a secluded place as an indicator that the girl was ready for sex, and an overwhelming majority (87\%) of respondents aged 36 and older answered yes.

In Ugandan culture, kissing is an activity thought to be done exclusively in private, which means that it is perceived differently than in most Western societies. Many Ugandans perceive penetrative sex as the next step after kissing, and many believe that a man cannot control his sexual urges once they have reached a certain point, which is used to excuse men's aggressive sexual actions. This myth about men not being able to control their sexual urges also affects perceptions of the severity of rape and may result in the refusal to label an act as rape.

Societal expectations of masculinity and femininity influence the conduct of men and women in sexual encounters. In a discussion on gender, the terms masculinity and femininity are used to identify a set of characteristics that are associated with men and women. In patriarchal societies, to be masculine is to possess qualities and traits associated with men, such as strength, dominance, aggression, control, courage, and being active and assertive, while femininity is associated with being submissive, passive, emotional, etc. The pressure to conform to these stereotypes can have negative consequences for both women (e.g., sexual assault) and men (e.g., jail time).

In a community where men are valued within the context of sexual virility, it may not be surprising that a man would be aggressive in his demand for sex. In a society that praises men for their sexual prowess, any possibility that a man's conduct may be interpreted as evidence of sexual "weakness" may cloud a man's interpretation of a woman's conduct. In such a context, a man is likely to opt for behavior that re-affirms his masculinity. Indeed, as argued by Ilkkaracan and Jolly (2007):

The societies we live in construct the right and wrong way to behave as men and women and these are mapped onto "right" and "wrong" sexual practices, beliefs and behaviors. Ideas that men should be macho can mean that sexual violence is expected rather than condemned. (p.3)

The 120 respondents were asked if women say no to sex when they mean yes, and $80 \%$ of them said yes, with $75 \%$ of men and a staggering $85 \%$ of women agreeing with the statement. A slighter larger share of people aged 35 and younger $(83 \%)$ agreed that a woman's no may be an agreement to sex. The perception that a woman's "no" to sex means "yes" could be rooted in the fact that women and men are socialized into believing that a virtuous woman is uninterested in sex or at the very least does not express her sexual desires. This is exacerbated by the stereotype of women as submissive and passive. In Uganda, a woman is 
not expected to make decisions, which means that her decision not to have sex can be safely ignored. These findings are in line with the observations of Ashlyn Olson (2009), who states:

Men are under the social impression that women mean yes when they say no. This is related to women's learned role of being passive and shy. It is related to the notion that a virtuous woman does not show interest in sex - feigns disinterest. (p.1)

Varga (2003) observes that cultural gender norms in many sub-Saharan African countries make girls feel that they cannot be in charge of their own sexuality or assertively communicate their sexual interests. These cultural norms promote an environment where a girl's "no" is reinterpreted as a "yes," which, combined with the perception that men cannot control their sexual urges, results in an environment supportive of "soft rape," or situations where a girl can be thought of as having sexually "teased" a boy into coercive sex (Balmer et al., 1997).

A study in South Africa found that one in four adults agree that rape usually happens because of something the woman has done or said (Kalichman et al., 2005). Similar to this finding, one of the young women I interviewed in the rape study stated: "We ladies often confuse men. Men never know what we want because we think it is a shame to say, 'I want."' She supported the sentiment that it is not rape if a man forces a woman to have sex with him if she is in his house. Many of the respondents said that it is in the "nature" of women to feign lack of interest in sex. In their view, even when a woman consents to sex, she will first have to show resistance. Another female respondent said, "The girl was not forced to go to the man's house. Why did she go there? She brought the rape upon herself." Another woman said, "When a man is not related to a girl, it is not easy for her to go to his house, she must have intended to have sex with him. The man's act is not rape because she took herself for the man." Finally, one young male respondent compared a sexual encounter between a man and a woman to what cocks and hens do. He said, "A rooster will dance, the hen will at first run around and around and the rooster will give chase. But eventually the hen will sit down and allow the cock to get on top." He interpreted the hen running around as the female searching for assurance that the rooster was serious in its pursuit.

These opinions are also in line with the observations made by Olson (2009), who stated:

Men think women play games to get them aroused and this leads to a whole jumble of confusion for both parties. There is a cultural view that women are timid but seductive which can lead men to believe a woman wants to be sexual when she does not. (p.1)

The views of the respondents also echoed what Mungwini and Matereke (2010) observe about the Shona of Zimbabwe: 
Among the Shona, there are cultural expectations that girls and women will resist any sexual advances from their male counterparts in order to prove that they are not sexually weak and promiscuous. It is for this reason that when a boy makes sexual advances to his girlfriend, he does not take seriously her attempts to say "no" because he anticipates them anyway, and this adds to his aggression. Commenting on these expectations in Zimbabwe, Musarurwa wrote that a woman has to struggle as a matter of duty and honor to defend her chastity. There is also the feeling that if she quickly and cheaply gives in her man will think she is a cheap woman who will sleep with anybody on request. Men are always faced with the problem to determine the amount of force they have to use. If it is too much it becomes rape. If it is too little it achieves nothing. They are in a dilemma. The mid-point is very elusive (Mungwiri and Matereke, 2020). Mungwiri and Matereke's (2020) opinion is that there are challenges in drawing boundaries between reasonable/ acceptable force and the kind of force which constitutes rape. (pp.1-19)

The majority of the participants in the rape study opined that a woman would likely lose a court case if she testified that the purported rape occurred in the man's house. The message from society is that men cannot be expected to control their sexual desires. In a patriarchal society, men learn to be aggressive in their sexual pursuits because they have been socialized to believe the myth that they cannot control their sexual urges. The findings in the rape study about the Ugandan society mirror what Mann (1994) said of American society, namely that extremely early in life, boys learn that they cannot control their hormones and are rarely expected to do so. And according to Olson (2009), there is an argument that hormone levels are to blame for sexual aggression that leads to rape. Many of the respondents in my rape study opined that if the man was not aggressive in terms of sex, that would be evidence of him not being a "real" man-he would be a "cock which does not crow." As a result, the man cannot be blamed for forcing a girl to have sex with him if she has led him on (e.g., kissing and/or going to the man's house), as he would (i) not be in position to control himself; and (ii) "naturally" interpret the woman's resistance as mere pretense, since a woman never says yes even when she wants sex. He would be entitled to interpret the romance and the location as consent and presume that the woman is pretending not to want to have sex. Surprisingly, a 70-year-old man was firm in his belief that as long as a woman makes it clear that she does not want to have sex, even if she expressed interest and led him on, using force would be considered rape.

Among the relatively few respondents who did not think that a man should force a woman into sex under the described circumstances, a staggering $97 \%$ of women and $62 \%$ of men said that the matter should not be handled in court, with $88 \%$ of respondents aged 35 years and older and $70 \%$ of respondents younger than 35 years old agreeing that the courts should not be involved. Some of the reasons given for not involving the courts include: (i) it was the woman's fault since she "led" the man on; and (ii) the two were lovers, which makes it a private matter. 
Prevailing social views of right and wrong ways to behave as a man or a woman influence sexual behavior. As revealed in the rape study, the idea that men should act "macho" often leads to tolerance rather than condemnation of male sexual violence against women. Like many other societies, Ugandan society has constructed an entire mythology that blames women for acts of sexual violence by men. One such myth is that in sexual matters, once a man starts, he cannot stop, since he has an uncontrollable sex drive. A woman should, therefore, make sure a man's sexual urge is not ignited. This means that a woman who exchanges nude pictures with a man and then visits his home must be blamed if the man forces her into sexual activity. Whatever the interpretation of non-consensual sex, these types of justificatory narratives are rooted in patriarchal practices that legitimize violence by men (i.e., the dominant group) against women (i.e., the disempowered group). The non-consensual sex act can, therefore, be viewed as an expression of power disparities between different groups based on social status, age, gender, etc.

\section{Judicial construction of gender and sexuality}

Community perceptions can affect judicial interpretations of a sexual encounter between a man and a woman. Judges must ensure that the defendant's right to a robust defense does not eclipse the victim's rights to be treated with dignity and respect. Unfortunately, several myths and stereotypic beliefs have found their way into the judicial construction of sexual encounters between men and women, which Barn and Kumari (2015) refer to as the infusion of rape mythology into the court process. An overwhelming majority of the 120 respondents believed that women often give mixed signals and that the circumstances in which a sexual encounter takes place can be the basis of inferred consent. For example, in the view of many of the respondents, the voluntary presence of a woman in a man's private space such as his home, the continuous acceptance of money and other favors from a man, and a woman's voluntary engagement in intimacy in a secluded place all justify a man's belief that the woman has provided her consent (albeit implied) to penetrative sex. These views implicitly support the legal notion from DPP $v$. Morgan (supra) that a man should not be convicted of rape if he believed that the woman was consenting to sex. The implicit message is that it is the responsibility of women to refrain from doing anything that may be interpreted as readiness to engage in penetrative sex.

In the Zuma rape trial, the accused stated, "The complainant visited my home $\ldots$ and stayed over for the night. This was of her own volition. At no stage did I believe that the sexual intercourse was against the will of the complainant" (The State v. Jacob Gedleyihlekisa Zuma, 2006). The complainant stated that the accused had invited her to his house, and she testified that it was the accused who suggested that she stay over for the night. More importantly, the complainant testified that the accused had not asked for her consent before he had intercourse with her. She answered "no" to the question: "Did you give him your consent or was there anything in your conduct which could have led the accused to believe that you gave him consent to have intercourse with you?" 


\section{Lillian Tibatemwa-Ekirikubinza}

In the rape trial, one of the factual issues that seemed important in determining the guilt of the accused was whether the woman's presence in the accused's home was initiated by the complainant. After analyzing the evidence of the accused and the complainant, the judge stated:

It is in dispute as to whether the accused invited (the complainant) to go his home or whether she invited herself. It is common cause that the complainant stayed for the night. It is in dispute whether the accused invited her to stay over or whether the complainant indicated that she would be staying over. The testimony of the accused's daughter supports the accused's evidence that it was the complainant who decided to stay the night.

The results of the rape study show that many Ugandans believe a woman's consent to sex is implied rather than explicitly given. In the Zuma rape trial, the judge emphasized:

Prior to the rape and in the preceding two months, the complainant had sent 54 sms messages to the accused. It appears that a change in the tone of the sms messages had also taken place in that they ended off with "love, hugs and kisses." It appears as if the complainant was seeking to make regular contact with the accused. In the accused's house the complainant walked around in a kanga with no underwear which prompted Duduzile Zuma (the accused's daughter) to say that she was inappropriately dressed.

One can infer that in the opinion of the judge, the complainant's conduct prior to the sexual encounter was evidence that she was interested in sex with the accused.

The ruling in the DPP v. Morgan case was restated in the Zuma trial: "Rape ... means ... intentional sexual intercourse had to take place with the accused knowing that there was no consent by the complainant." This is in line with the inherent message from many of the participants in the rape study that a woman should not lead a man on if she is not willing to have sex.

In summarizing the evidence of the complainant, the judge in the Zuma rape trial noted:

She also stated that the accused did not ask her for her consent before he had intercourse with her. The leading question was then put "Did you give him your consent or was there anything in your conduct which could have led the accused to believe that you gave him consent to have intercourse with you?" The answer was "No I did nothing to make him believe that, no."

The specific question put to the complainant is especially revealing. Mr. Zuma said that the sex act occurred in his bedroom and that the woman had entered the room on her own accord. He also testified that she had signaled her interest in sex earlier in the evening by wearing a skirt and sitting with her legs uncrossed 
as she faced him. Furthermore, the judge noted that the complainant confirmed that she only had on a kanga ${ }^{6}$ without any underwear when she went to the accused before the sexual encounter. The message of the judge to the complainant (albeit implicit) was that it was her fault and that her conduct led the man into believing she consented to sex.

The societal perception that sex is expected in exchange for financial favors, which means that the woman's consent to sex is assumed, may also have played a part in what took place in the Zuma-Kwezi sexual encounter. The complainant had requested financial assistance from the accused to attend university, and $\mathrm{Mr}$. Zuma had agreed to fund her. It was also reported that the accused at one time paid the airfare for the complainant to travel and see her mother. The monetization of women's bodies is also clearly exhibited during events that happened after the alleged rape. For example, the complainant's mother and the accused had discussed compensation for the alleged rape. The accused testified that during the meeting with the complainant's mother, he said he was prepared to assist the complainant to go to London for further studies. He had also said to the mother that he was willing to assist with a fence at the complainant's parental home in KwaZulu Natal.

Another finding from the rape study is that many respondents believed that women sometimes show a fake lack of interest in sex. This can be interpreted to mean that women tell lies about sexual encounters. It is a trite principle of the law of evidence that a conviction can be based on the testimony of a single witness. To prove any fact, what matters is the quality and not the quantity of evidence. And yet historically, courts have as a matter of practice warned themselves of "the danger" of acting on the uncorroborated evidence of a complainant in a sexual assault case, which has been the cautionary rule in cases involving sexual offenses. ${ }^{7}$

Reasons given for the need of evidence that is independent of the victim's story in sexual assault cases have their origin in the opinion of the Chief Justice of England, Sir Mathew Hale, who said that rape must be examined with greater caution than any other crime, as it is easy to charge and difficult to defend (Tibatemwa-Ekirikubinza, 2015, p.38). A similar opinion was expressed by Lord Justice Salmon: "In cases of alleged sexual offences human experience has shown that in these cases girls and women do sometimes tell an entirely false story which is very easy to fabricate but extremely difficult to refute" (R v Henry and Manning, 1969, p.153). The belief that women lie about sexual encounters has dire consequences for victims of rape, because most acquittals depend on the credibility of the complainant as a witness.

\section{Next steps}

The United Nations Convention on the Elimination of All Forms of Discrimination's (CEDAW) General Recommendation No. 33 on women's access to justice urges countries to modify or transform harmful gender stereotypes and eliminate wrongful gender stereotyping (CEDAW, 2015). Gender 
stereotyping is harmful when it results in violations of human rights. An example is the failure of the justice system to hold perpetrators of sexual violence accountable because of stereotypes of women's appropriate (sexual) behavior. Courts in the common law legal system operate on the basis of the doctrine of stare decisis, ${ }^{8}$ which obligates courts to be guided by precedents when determining cases. Inherent in this principle is the expectation that courts will decide cases according to consistent principled rules, so that similar facts will yield similar and predictable outcomes. One of the negative consequences of this doctrine is that it can result in the judicial perpetuation of harmful stereotypes.

Judges, just like all people, hold preconceived and often strongly held values and beliefs. Judicial authorities must take steps to ensure that prejudices and harmful gender stereotypes do not undermine the credibility of victims of SGBV. Judges must address biases that lead to victim-blaming or mistrust in the victim's story and ultimately, putting the victim on trial. This, however, presupposes that judicial officers are aware of the unintended consequences of stare decisis. They need to be willing to interrogate previous court decisions from a human rights perspective and, where appropriate, rule that previous decisions are unconstitutional.

Efforts to improve women's access to justice often call for judicial activismthe process by which new juristic principles evolve and are used to amend existing laws to bring them in conformity with current expectations of society (Ukey, 2015). For example, the historical rule on corroboration in sexual assault cases was nullified through judicial activism in the case of Uganda v. Peter Matovu. In this case, Judge Lugayizi declined to apply the rule on corroboration because of its discriminatory effect on women, which was considered a violation of both the country's constitution and Uganda's obligations under CEDAW. The judge recognized the inherent stereotyping of women and stated that the

Court had not come across any empirical data or basis for the belief that women are greater liars than men or, for that matter, that they are much more likely to lie than to say the truth in matters concerning sexual allegations. For that reason, it seems that both the belief and the resultant rule have no logical basis.

(Uganda v. Peter Matovu, 2001)

Moreover, in the case of Ntambala v. Uganda (2015), the Supreme Court stated that the court needed to depart from its previous decision, which held that the cautionary rule was a requirement in sexual assault prosecutions because the rule violated Uganda's constitutional provisions of equality before the law and equal protection under the law. It is clear that in both Uganda v. Peter Matovu and Ntambala v. Uganda, there was a deliberate decision by the courts not to follow precedent.

An effective judicial response to sexual assault calls for efforts to ensure that judges have the required expertise to understand SGBV. For judges to be able to challenge judicial precedents from a gender perspective, they need the skills 
and tools necessary to recognize gender bias in judicial practice and apply human rights and gender mainstreaming to improve women's access to justice.

\section{Conclusion}

A positive effect of the pandemic is that it has re-energized efforts to evaluate the systemic barriers faced by women in their attempt to access justice. For example, the Medical-Legal Committee on Gender Based Violence was established in August 2020 under the MGLSD to coordinate efforts of various partner institutions ${ }^{9}$ related to SGBV, especially during the pandemic. The committee shares information on victims of SGBV who are in need of medical and legal assistance; advocates for genderbased budgeting; and performs field assessments on the prevention of and response to SGBV. Committee members have visited various districts to ensure that medical and legal services are available to survivors of SGBV, identify key challenges, and suggest policy recommendations. However, the barriers to women's access to justice in Uganda were not created by the current emergency but are rooted in women's subordination in a patriarchal society. To ensure that women are treated fairly in the justice system, all judicial authorities need to adopt a gender perspective in their work and assess the implications for both women and men of any planned policy action, including legislation, administrative process, policy program, or emergency measure to mitigate the impact of the COVID-19 pandemic.

\section{Notes}

1 Defilement refers to sexual activity with a person under the age of 18 , while rape refers to having sexual intercourse with a woman without her consent.

2 The Katwe and Kabalagala police stations were selected because the heads of the two stations responded promptly to the request for information and were willing to allow their officers at the gender desk to be interviewed. To process data from 50 case files covering the period of March to October, 2020, a data collection tool was developed that included information on (i) date of occurrence; (ii) nature of the offense; (iii) relationship between the perpetrator and victim; (iv) age of the perpetrator and victim; (v) place of occurrence; and (vi) a brief narrative on how the offense was committed.

3 Boda bodas are bicycle and motorcycle taxis commonly found in East Africa.

4 With movement restrictions and the lockdown of small businesses, service providers such as hair salons and restaurants started offering their services in people's homes.

5 Based on an interview with the Assistant Director of Public Prosecution/Head of Gender, Children and Sexual Offences at National Level, Ms. Samali Wakooli, and data collected from ten police stations: Entebbe, Kajjansi, Kasangati, Kira, Nakawa, Nabweru, Luzira, Matugga, Wakiso, and Soroti.

6 The kanga is a colorful fabric worn by women and occasionally by men throughout the African Great Lakes region. Source: https://en.wikipedia.org/wiki/Kanga_(garment). In East Africa, it is also referred to as Leso or lesu.

7 In East Africa, the leading authority on this rule has been the decision of the East African Court of Appeal in Chila and Another v. R. ${ }^{49}$

8 Stare decisis means let the decision stand.

9 The Ministry of Health, the Office of Public Prosecutions, the Ministry of Gender, and the Uganda Police. 


\section{Constitutions and legislation}

Constitution of the Republic of Uganda. (1995).

Penal Code Act. (1950). Uganda Legal Information Institute.

\section{Case law}

DPP v. Morgan, AC. No. 182, (House of Lords, 1976).

Ntambala v. Uganda, Cr. App. No. 34 of 2015. [2018] UGSC 1 (UGSC, Jan. 18, 2018).

$R v$. Henry and Manning, 53 Cr. App. R. 150 (1969).

Uganda v. Peter Matovu, Criminal Case No. 146, (High Court, 2001).

The State v. Jacob Gedleyihlekisa Zuma, (High Court of South Africa, Witwatersrand Local Division, May 8, 2006). (Unreported)

\section{References}

Abrams, D., Viki, G.T., Masser, B., \& Bohner, G. (2003, January). Perceptions of stranger and acquaintance rape: The role of benevolent and hostile sexism in victim blame and rape proclivity. Journal of Personality and Social Psychology, 84(1), 111-125. https://pu bmed.ncbi.nlm.nih.gov/12518974/

Balmer, D.H., Gikundi, E., Billingsley, M.C., Kihuho, F.G., Kimani, M., Wang'ondu, J., \& Njoroge, H. (1997). Adolescent knowledge, values, and coping strategies: Implications for health in Sub-Saharan Africa. Journal of Adolescent Health, 21(1), 33-38. https:// pubmed.ncbi.nlm.nih.gov/9215508/

Barn, R., \& Kumari, V. (2015). Understanding complainant credibility in rape appeals: A case study of high court judgments and judges' perspectives in india. The British Journal of Criminology, 55(3), 435-453.

Constitution of Uganda (1995). https://statehouse.go.ug

Convention on the Elimination of All Forms of Discrimination against Women (CEDAW) (n.d.). General Recommendation No. 33 on Women's Access to Justice, 23 July 2015. CEDAW/C/GC/33, https://tbinternet.ohchr.org/Treaties/CEDAW/Shared \%20Documents/1_Global/CEDAW_C_GC_33_7767_E.pdf

Giarruso, R., Johnson, P., Goodchilds, J., \& Zellman, G. (1979). Adolescents' cues and signals: Sex and assault. presented at Western Psychological Association Meeting Symposium. Acquaintance Rape and Adolescent Sexuality, San Diego, CA, April 1979.

Huaxia (2020, March 18). Ethiopia closes federal courts for 15 days in latest antiCOVID-19 measures. Xinhua.Net. http://www.xinhuanet.com/english/2020-03/18/c _138892587.htm

Iikkaracan, P., \& Jolly, S. (2007, January). Gender and Sexuality. Bridge. https://www.bri dge.ids.ac.uk/reports/CEP-Sexuality-OR.pdf

International Conference of the Red Cross and Red Crescent (32nd RCRC Conference) (2015, December 8-10). 32IC/15/R3. Resolution 3: Sexual and gender-based violence: Joint action on prevention and response. http://rcrcconference.org/app//uploads/2015 104/32IC-AR-on-Sexual-and-gender-based-violence_EN.pdf

Kalemba, K. (2015, December 19). A 'Disciplined' Dog Sleeping next to a Bucket of Meat in Kisoga Town, Mukno District. Saturday Vision.

Kalichman, S.C., Simbayi, L.C., Kaufman, M., Cain, D., Cherry, C., Jooste, S., \& Mathiti, V. (2005). Gender attitudes, sexual violence, and HIV/AIDS risks among men and 
women in Cape Town, South Africa. Journal of Sex Research, 42(4), 299-305. https:// doi.org/10.1080/00224490509552285

Kamya, J.R.Y. (2020). SGBV During the COVID-19 Pandemic in Uganda [Unpublished report]. ICGLR-RTF.

Lonsway, K.A., \& Fitzgerald, L.F. (1994). Rape myths: In review. Psychology of Women Quarterly, 18(2), 133-164. https://doi.org/10.1111/j.1471-6402.1994.tb00448.x

Mann, J. (1994). The Difference: Growing up Female in America. Warner Books.

McHale, M.J. (2016, February 2). What does access to justice mean? UVicACE. http:// www.uvicace.com/blog/2016/2/2/what-does-access-to-justice-mean

Moore, A.M., Biddlecom, A.E., \& Zulu, E.M. (2007). Prevalence and meanings of exchange of money or gifts for sex in unmarried adolescent sexual relationships in SubSaharan Africa. African Journal of Reproductive Health, 11(3), 44-61.

Mungwini, P., \& Matereke, K. (2010, August). Rape, sexual politics and the construction of manhood among the Shona of Zimbabwe: Some philosophical reflections. African Journals Online, 2(1). https://www.ajol.info//index.php/tp/article/view/57662

Mungwiri, P., \& Matereke, K. (June 2020). Thought and Practice : A Journal of the Philosophical Asssociation of Kenya (PAK) New Series, 2(1), 1-19. http://ajol.info/index .php.tp/index

Musiime, E. (2020). The disruption of women's rights in the face of the COVID-19 pandemic in Uganda. Institute for African Women in Law. https://www.africanwomeni nlaw.com/amp/the-disruption-of-women-s-rights-in-the-face-of-the-covid-19-pandem ic-in-uganda?_twitter_impression=true

Olson, A. (2009). Gender socialization and rape. Wolf's Sociology. 204. http://www.srwolf .com/wolfsoc/soc204/204archives/2009/03/19/gender_socialization_and_rape.php

Peterman, A., Potts, A., O’Donnell, M., Thompson, K., Shah, N., Oertelt-Prigione, S., \& Gelder, N. van (2020, April 1). Pandemics and Violence Against Women and Children. (Working paper 528). Center for Global Development. https://www.cgdev.org/sites/de fault/files/pandemics-and-vawg-april2.pdf

Save the Children (2020, May). Keeping Children Safe in Uganda's Covid-19 Response. Save the Children Resource Center. https://resourcecentre.savethechildren.net/node/17615 /pdf/Joining\%20Forces\%20-\%20Protecting\%20children\%20during\%20Covid-19\%20 in\%20Uganda.pdf

Songa, M. (2020, September 28). Ministry of Gender Launches Mobile App to Strengthen Reporting of Sexual Violence and Dissemination of Reproductive Health Information. United Nations Population Fund. https://uganda.unfpa.org/en/news/ministry-gender-launches -mobile-app-strengthen-reporting-sexual-violence-and-dissemination

Stets, J.E., \& Pirog-Good, M.A. (1989). Patterns of physical and sexual abuse for men and women in dating relationships: A descriptive analysis. Journal of Family Violence, 4(1), 63-76. https://doi.org/10.1007/BF00985657

Tibatemwa-Ekirikubinza, L. (2015). Criminal Law in Uganda: Sexual Assaults and Offences Against Morality. Fountain Publishers.

Ukey, K.L. (2015). Judicial activism: Principles and practice: A Bird's Eye view of theory, practice and current trends in global/Indian scenario. Online International Interdisciplinary Research Journal, ISSN 2249-9598. http://www.oiirj.org/oiirj/july-aug 2015/19.pdf

United Nations High Commissioner for Refugees (UNHCR) (2020, August 11). East and Horn Of Africa, and the Great Lakes Region SGBV: Regional Overview, March-July 2020. Reliefweb. https://reliefweb.int/report/burundi/east-and-horn-africa-and-great-lakes-r egion-sgbv-regional-overview-march-july-2020 


\section{Lillian Tibatemwa-Ekirikubinza}

Varga, C.A. (2003). How gender roles influence sexual and reproductive health among South African adolescents. Studies in Family Planning, 34(3), 160-172. https://pubmed. ncbi.nlm.nih.gov/14558319/

Women of Uganda Network (2020, February). Bridging the Digital Gender Gap in Uganda: An Assessment of Women's Rights Online Based on the Principles of the African Declaration of Internet Rights and Freedoms. https://africaninternetrights.org/sites/default/files/Bridgi ng-the-Digital-Gender-Gap-in-Uganda-WOUGNET.pdf

World Vision (2020, August 21). COVID-19 Aftershocks: Access Denied Teenage Pregnancy Threatens to Block a Million Girls Across Sub-Saharan Africa from Returning to School. Reliefweb. https://reliefweb.int/report/world/covid-19-aftershocks-access-deniedteenage-pregnancy-threatens-block-million-girls 